\title{
Feeding habits of the cockfish, Callorhinchus callorynchus (Holocephali: Callorhinchidae) a from off northern Argentina
}

Correspondence: Jorge M. Roman jroman@mdp.edu

Submitted September 21, 2018

Accepted December 5, 2019

by Lisa Whitenack

Published April 20, 2020

\section{Jorge M. Roman ${ }^{1,2}$, $\odot$ Melisa A. Chierichetti ${ }^{3}$, $\odot$ Santiago A. Barbini ${ }^{1,3}$ and $\odot$ Lorena B. Scenna ${ }^{1,3}$}

The feeding habits of Callorhinchus callorynchus were investigated in coastal waters off northern Argentina. The effect of body size, seasons and regions was evaluated on female diet composition using a multiple-hypothesis modelling approach. Callorhinchus callorynchus fed mainly on bivalves (55.61\% PSIRI), followed by brachyuran crabs (10.62\% PSIRI) and isopods (10.13\% PSIRI). Callorhinchus callorynchus females showed changes in the diet composition with increasing body size and also between seasons and regions. Further, this species is able to consume larger bivalves as it grows. Trophic level was 3.15, characterizing it as a secondary consumer. We conclude that $C$. callorynchus showed a behavior of crushing hard prey, mainly on bivalves, brachyuran, gastropods and anomuran crabs. Females of this species shift their diet with increasing body size and in response to seasonal and regional changes in prey abundance or distribution.

Keywords: Chondrichthyes, Diet, Ontogenetic shifts, Southwest Atlantic, Trophic level.
Online version ISSN 1982-0224

Print version ISSN 1679-6225

Neotrop. Ichthyol.

vol. 18, no. 1, Maringá 2020

Epub, Apr 17, 2020
1 Instituto de Investigaciones Marinas y Costeras, Universidad Nacional de Mar del Plata, Funes 3350, B7602AYL, Mar del Plata Argentina. (JMR) jroman@mdp.edu.ar

2 Comisión de Investigaciones Científicas, calle 526 e/ 10 y 11, La Plata, Argentina. (MAC) mchierichetti@mdp.edu.ar

3 Consejo Nacional de Investigaciones Científicas y Técnicas, Avenida Rivadavia 1917. C1033AAJ, Ciudad Autónoma de Buenos Aires, Argentina. (SAB) sbarbini@mdp.edu.ar; (LBS) lscenna@mdp.edu.ar 
Los hábitos alimentarios de Callorhinchus callorynchus fueron investigados en las aguas costeras del norte de Argentina. Se evaluó el efecto del tamaño del cuerpo, la temporada y la región sobre la composición de la dieta de las hembras mediante un enfoque de modelado de múltiples hipótesis. Callorhinchus callorynchus se alimentó principalmente de bivalvos (55,61\% PSIRI), seguido de cangrejos brachyuras (10,62\% PSIRI) y de isópodos (10,13\% PSIRI). Las hembras de C. callorynchus presentaron cambios en la dieta con incremento del tamaño del cuerpo, la temporada y la región. Además, esta especie es capaz de consumir bivalvos de mayor tamaño a medida que incrementa el tamaño del cuerpo. El nivel trófico fue calculado en 3,15 , caracterizando a esta especie como un consumidor secundario. Concluimos que C. callorynchus presentó un comportamiento de triturador de presas duras, principalmente bivalvos, cangrejos y gasterópodos. Las hembras de esta especie cambian su dieta con el incremento del tamaño del cuerpo y en respuesta a cambios temporales y regionales en la abundancia y distribución de sus presas.

Palabras clave: Atlántico Sudoccidental, Cambios ontogenéticos, Condrictios, Dieta, Nivel trófico.

\section{INTRODUCTION}

The cockfish, Callorhinchus callorynchus (Linnaeus, 1758) (Callorhinchidae), is an endemic holocephalan from South America, occurring from $23^{\circ} \mathrm{S}$ in the Southwestern Atlantic to $18^{\circ} \mathrm{S}$ in the Southeastern Pacific (López et al., 2000; Didier, 2004; Cousseau, Perrotta, 2013). This species inhabits depths ranging from the shoreline to $200 \mathrm{~m}$ (Cousseau, Perrotta, 2013). It is captured year-round as part of commercial bottom trawl fisheries in Argentina, Chile and Peru (Dagit et al., 2007; Consejo Federal Pesquero, 2009). In northern Argentina, the area with the highest catch and landings of chondrichthyans, C. callorynchus represents an important resource for recreational and artisanal fisheries (Massa et al., 2004; Consejo Federal Pesquero, 2009; Cedrola et al., 2011; Lucifora et al., 2012; Cousseau, Perrotta, 2013). In this area the abundance of this species has declined by nearly 50\% between 1994 to 1999, but today this information is unknown (Massa et al., 2004; Consejo Federal Pesquero, 2009). However, the International Union for Conservation of Nature (IUCN) categorized C. callorynchus in South America as least concern (Dagit et al., 2007).

Distribution and reproductive biology of C. callorynchus have been studied from individuals collected in different marine regions, such as in San Matías Gulf, northern

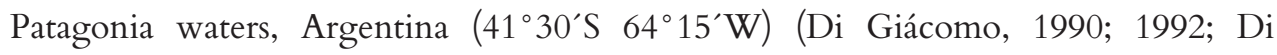
Giácomo, Perier, 1994; Bernasconi et al., 2015a, b), in coastal waters off northern Argentina $\left(36^{\circ}-38^{\circ} \mathrm{S} 56^{\circ}-57^{\circ} \mathrm{W}\right)$ (Chierichetti et al., 2017), and off Coquimbo, Chile (30¹5'S 70³0'W) (Alarcón et al., 2011). Additionally, reproductive observations in coastal waters off northern Argentina, indicate that this area is not a nursery ground for C. callorynchus (Cousseau, Perrotta, 2013; Chierichetti et al., 2017). In contrast, little has 
been studied regarding the diet and feeding habits of the cockfish in waters of South America (Di Giácomo et al., 1994; Di Giácomo, Perier, 1996; Cousseau, Perrotta, 2013).

Off the north coast off Argentina, the feeding habits of several species of chondrichthyans have been well documented. These species exhibited sexual, ontogenetic, regional and/or seasonal changes in their dietary composition (e.g, sharks, Lucifora et al., 2006; 2009; Belleggia et al., 2012; skates, Barbini, Lucifora, 2011; 2012; 2016; apron ray, Spath et al., 2012; and mylibatoid rays Ruocco, Lucifora, 2016). Previous studies of the feeding habits of C. callorynchus in coastal waters of the San Matías Gulf (northern Patagonia) indicated that the diet composition was dominated by bivalve molluscs, mainly scallops, and that diet composition changed in relation to ontogeny (Di Giácomo et al., 1994; Di Giácomo, Perier, 1996). Conversely, feeding habits of this species in northern Argentina coastal waters are poorly known: scarce data are provided by Rios, Pereira (1986) concerning only qualitative aspects of its diet. Despite advances in our understanding of the biology of C.callorynchus, there are major gaps in our knowledge on feeding habits and some questions arise: are bivalves the main prey item in coastal waters off northern Argentina?; do ontogenetic, regional and seasonal differences exist in the dietary composition of C. callorynchus? Therefore, the purpose of this study was to determine the feeding habits of C. callorynchus in northern Argentinean coastal waters. Our specific aims were to: (1) describe diet composition; (2) identify changes in diet with maturity stage, body size, region and season; (3) examine relationships between predator size and prey size; and (4) determine the trophic level of C. callorynchus. Evaluating the effects of specific characteristics (maturity stage, body size, region and season) on the feeding habits of this species, will allow us insights into ways in which the cockfish exploits food resources and to understand how this species influences the dynamics of predator-prey interactions in this area. Basic ecological data, such as diet composition, constitutes one of so many necessary tools to develop a suitable plan of marine ecosystem conservation (Cochrane, 2002; Thrush, Dayton, 2010).

\section{MATERIAL AND METHODS}

Study area and sampling. The study area is located between $36^{\circ}$ and $40^{\circ} \mathrm{S}$ (Fig. 1) and consists of two coastal systems. A stratified coastal zone (north of $37^{\circ} \mathrm{S}$ ) influenced by the discharge of the Río de la Plata and a homogeneous coastal zone (south of $37^{\circ}$ S), that comprises an estuarine system called El Rincón, characterized by the discharge of the Río Negro and Río Colorado and discharges of high salinity waters of the San Matías Gulf (Guerrero, Piola, 1997; Lucas et al., 2005) (Fig. 1).

Individuals of C. callorynchus were obtained from June to December between 2011 and 2014, by small-scale artisanal fishermen using longlines or commercial bottom trawlers. For each individual captured, precaudal length (PCL, mm), total body mass (in g), sex and maturity stage (immature or mature) were recorded. Maturity stage was determined according to the degree of calcification of the claspers and the development of testes and reproductive ducts in males, and to the observation of the uteri, oviductal glands and ovarian follicles in females (Chierichetti et al., 2017). The guts were removed and frozen at $-20^{\circ} \mathrm{C}$ for subsequent analyses in the laboratory. 


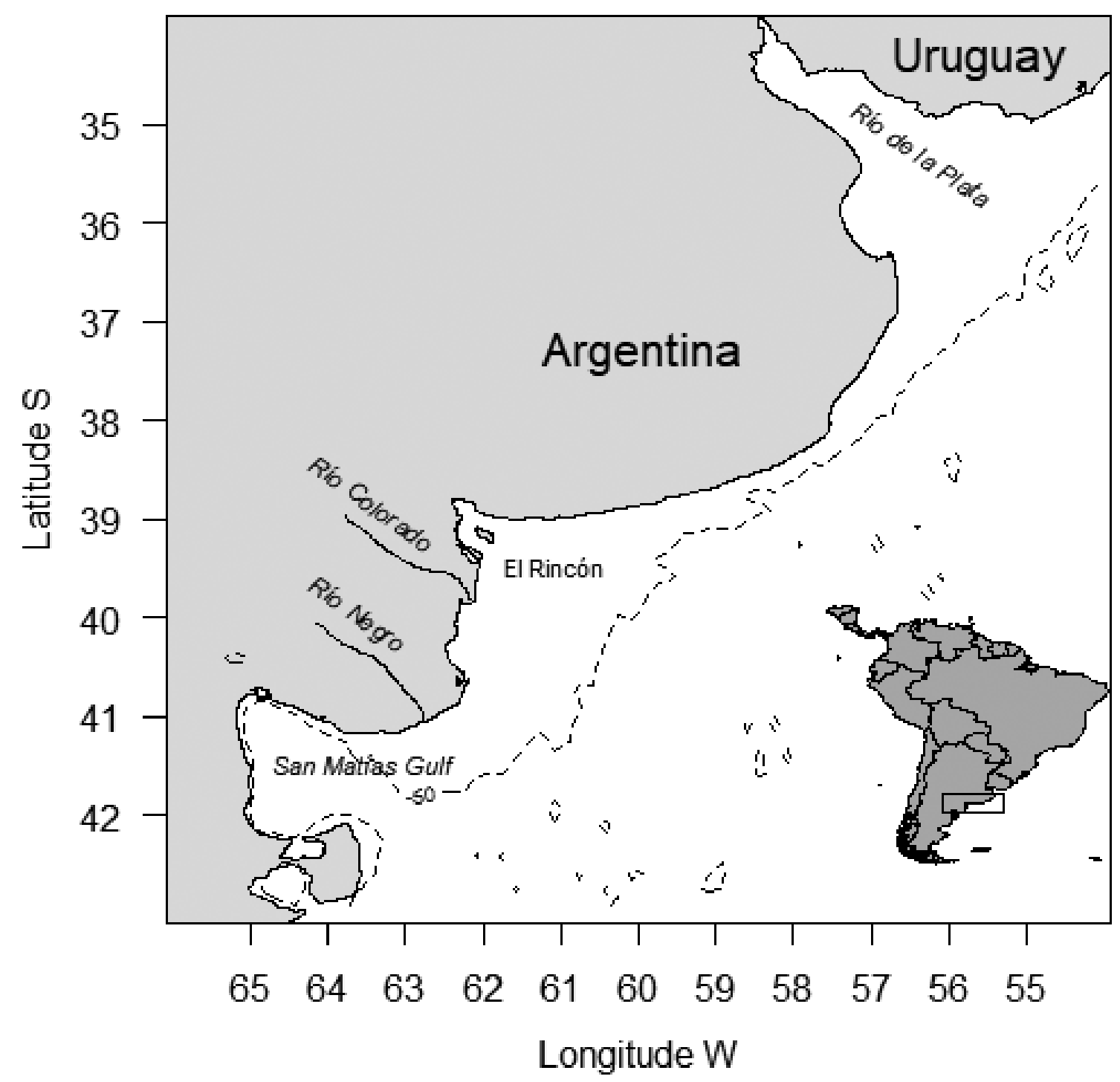

FIGURE 1 I Study area showing where individuals of Callorhinchus callorynchus were captured off northern Argentina. The rectangle in the inset shows the location of the study area in South America.

Diet composition and analysis. Gut contents were sorted and identified to the lowest possible taxonomic level, using reference collections and published catalogues. Prey were counted and their wet weights recorded $( \pm 0.01 \mathrm{~g})$. When possible, carapace width (CW) of brachyuran crabs and valve width (VW) of bivalves were measured. To assess the importance of each prey and allow comparisons with other studies, the composition of the diet was established by the prey-specific index of relative importance (\% PSIRI $_{\mathrm{i}}$ ) (Brown et al., 2012), by using the equation:

$$
\operatorname{PSIRI}_{i}=\frac{\% F O_{i} x\left(\% P N_{i}+\% P W_{i}\right)}{2}
$$


where $\% \mathrm{FO}_{\mathrm{i}}$ is the number of guts containing prey category $i$, divided by the number of guts $n, \% \mathrm{PN}_{\mathrm{i}}$, and $\% \mathrm{PW}_{\mathrm{i}}$ are prey-specific abundance in terms of percent number and percent weight, respectively. The prey-specific abundance $\left(\% \mathrm{PA}_{\mathrm{i}}\right)$ was calculated following Brown et al. (2012):

$$
\% P A_{i}=\frac{\sum_{j=1}^{n} \% A_{i j}}{n_{i}}
$$

where $\% \mathrm{~A}_{i j}$ is the abundance by counts $\left(\% \mathrm{PN}_{\mathrm{i}}\right)$ or weight $\left(\% \mathrm{PW}_{\mathrm{i}}\right)$ of the prey category $i$ in gut sample $j$ and $\mathrm{n}_{i}$ is the number of gut contents containing prey $i$.

To determine whether a sufficient number of individuals was sampled to conduct statistical analyses, the order of guts was randomised 100 times and the accumulation prey curve was plotted as a function of sample size. Sample size was considered sufficient to describe diet if the cumulation prey curve reached an asymptote (Ferry, Cailliet, 1996).

For the statistical analyses, prey were grouped into seven zoological categories: bivalves, gastropods, brachyuran crabs, anomuran crabs, isopods, amphipods and cumaceans. These categories were chosen because they reflected the ecological varibility of the diet of $C$. callorynchus. To identify changes in the diet with maturity stage (immature or mature), body size (PCL), region (north, center and south) and season (warm = October-December; cold = June-September), generalized linear models (GLM) were fitted (Venables, Ripley, 2002). Due to the low number of individuals from the southern region, and the low overall number of males in the total sample, the generalized linear models were adjusted only for females of the north and center region.

For each prey category, models were built where the response variable was the number of prey consumed and the independent variables were maturity stage, PCL, region and season. Also, models with combinations between PCL + region, PCL + season, maturity stage + region, maturity stage + season, season + region as independent variables were fitted. A model without any of the independent variables (i.e., null model) was fitted to asses whether none of the tested variables had an effect on the consumption of prey categories (Lucifora et al., 2009; Barbini, Lucifora, 2011). All models had a negative binomial error distribution because response variables had a high number of zero-values and variance much greater than the mean, and a log link (Crawley, 2005). A multiple-hypothesis model approach was used to identify the best model explaining the consumption of a given prey (Anderson et al., 2000; Franklin et al., 2001) (Tab. 1).

For each model, the Akaike information criterion (AIC) and the Akaike's weight $(w)$ were calculated. The AIC value for a given model represents the information lost, so the model with the lowest AIC was selected as the best model among the set of models proposed. The $w$ value was calculated to obtain the likelihood of each competing model given the data (Franklin et al., 2001; Johnson, Omland, 2004). If $w$ did not provide strong support for any model fitted, we used model averaging to estimate the parameters of the variables included in the best model (Symonds, Moussalli, 2011).

To examine relationships between predator size and prey size, we used PCL of C. callorynchus and CW of crabs and VW of bivalves. Regressions on the 5, 50 and 95\% quantiles were fitted in order to test an increase in minimun, medium and maximun 
prey size with increasing PCL, respectively (Scharf et al., 1998).

The trophic level of C. callorynchus was calculated using the trophic index $\left(\mathrm{TL}_{\mathrm{k}}\right)$, to determine its position within the food web applying the method proposed by Cortés (1999) as:

$$
T L_{k}=1+\left(\sum_{j=1}^{n} P_{j} \times T L_{j}\right)
$$

where $\mathrm{TL}_{\mathrm{J}}$ is the trophic level of each prey category $\mathrm{j}$ and $\mathrm{P}_{\mathrm{j}}$ is the proportion of each prey category $\mathrm{j}$ (using $\% \mathrm{~W}$ ) in the diet, and $\mathrm{n}$ is the total number of prey categories.

Seven prey categories were used to calculate this trophic level of C. callorynchus: bivalves, gastropods, brachyuran crabs, anomuran crabs, isopods, amphipods and cumaceans. Trophic level of each prey category was obtained from Ebert, Bizarro (2007). The observations were randomly sampled 100 times with replacement in order to obtain the frequency distribution of $\mathrm{TL}_{\mathrm{k}}$ and to get mean and standard deviation values. All statistical analyses were performed using the $\mathrm{R}$ statistical software, version 3.1.0 (R Development Core Team, 2019).

\section{RESULTS}

Overall diet. A total of 210 individuals, 180 females and 30 males, were sampled and $83.8 \%$ (176) of them contained food. Of the individuals containing food, 152 were females ranged from 390-630 mm PCL and weighing between 825-3330 g, and 24 were males ranged from 350-480 mm PCL and weighing between 640-1630 g (Fig. 2).

Overall, 9642 prey with a total weight of $2230 \mathrm{~g}$ were found in the guts. The accumulation prey curves reached an asymptote for all the groups considered, indicating that sample sizes were sufficient (Fig. 3).

In total, 64 different prey taxa were identified: 25 molluscs, 19 decapods, six isopods,

TABLE 1 I Models fitted between the number of consumed prey $(N)$ by females of Callorhinchus callorynchus and the independent variables. The categorical variables were maturity stage (immature and mature), region (north and center) and season (warm and cold) (PCL: precaudal length; *: null model).

\begin{tabular}{|c|c|}
\hline Numbers & Models \\
\hline 1 & $N \sim$ PCL \\
2 & $N \sim$ maturity stage \\
\hline 3 & $N \sim$ season \\
\hline 4 & $N \sim$ region \\
5 & $N \sim$ PCL + season \\
6 & $N \sim$ PCL + region \\
\hline 7 & $N \sim$ maturity stage + season \\
\hline 8 & $N \sim$ maturity stage + region \\
9 & $N \sim$ season + region \\
\hline $10^{*}$ & $N \sim 1$ \\
\hline
\end{tabular}




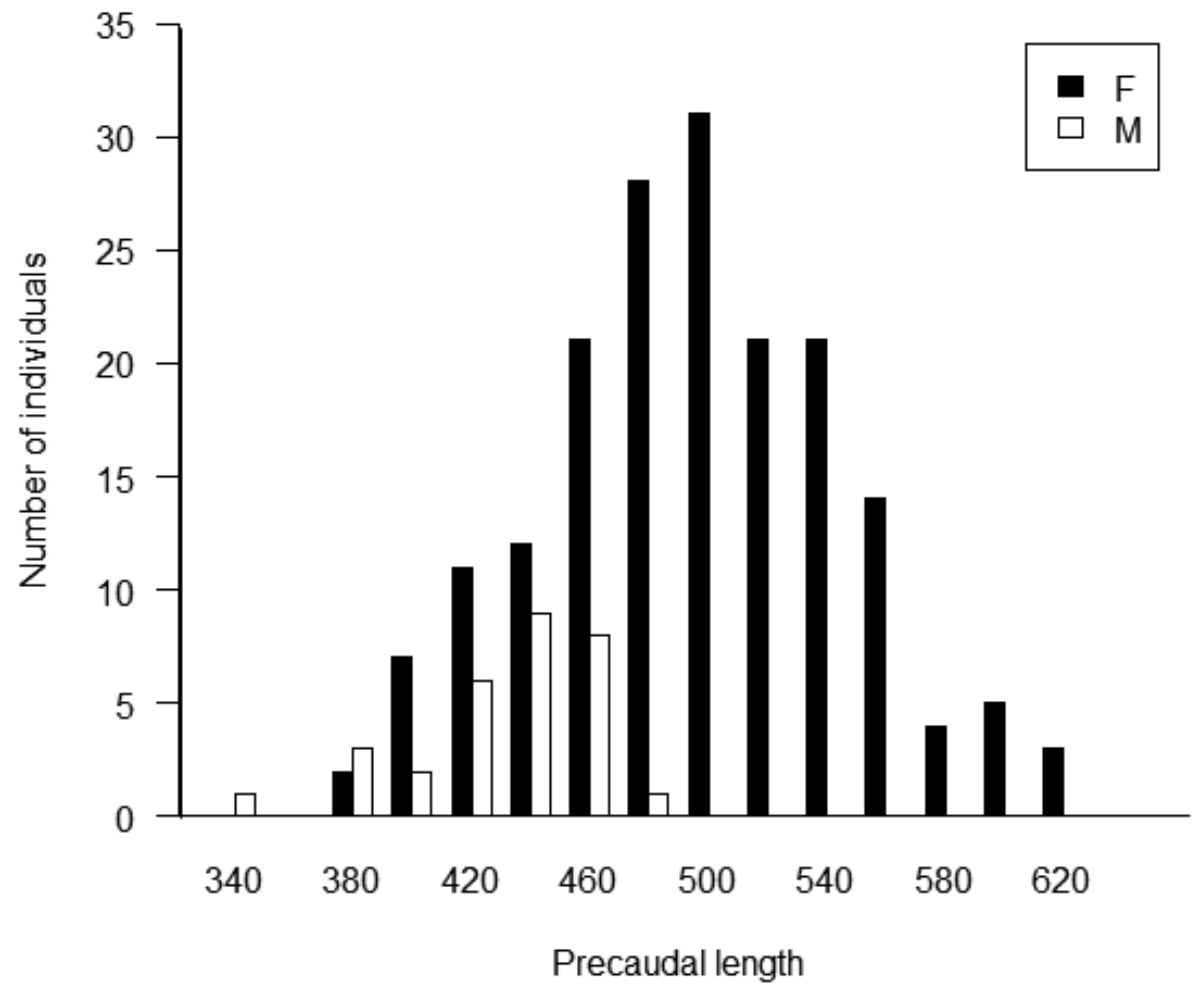

FIGURE 2 I Length-frequency distributions of Callorhinchus callorynchus for females (F) and males (M) off northern Argentina.

three polychaetes, three amphipods, three cumaceans, one teleost, one echinoderm, one bryozoan and one sipunculid (Tab. 2). In terms of \%PSIRI the diet of C. callorynchus was dominated mainly by bivalves. Brachyuran crabs, isopods, gastropods, anomuran crabs, amphipods and cumaceans were also consumed but in lower proportion. The most frequent prey category was bivalves. Gastropods and isopods showed the same frequency of occurrence in the diet of C. callorynchus. The most important prey categories according to prey-specific abundance by number and weight were bivalves and unidentified Teleostei, followed by isopods and brachyuran crabs in term of the $\% \mathrm{PN}$ and $\% \mathrm{PW}$. Among bivalves, Amiantis purpurata was the most consumed prey species in terms of $\% \mathrm{PN}, \% \mathrm{PW}, \% \mathrm{FO}$ and \%PSIRI. Mytilus edulis was the second most important in terms of \%PSIRI, followed by Corbula patagonica and Mactra marplatensis. Unidentified gastropods were the most frequent prey species in the diet of the $C$. callorynchus. The crab Libinia spinosa was the most important prey species among crustaceans in terms of $\% \mathrm{PN}$ and $\% \mathrm{PW}$. Amphipods belonging to the Ampeliscidae family and the crab Blepharipoda doelloi, were the second most important in terms of the $\% \mathrm{PN}$ and \%PW among crustaceans.

The diet composition of both sexes was composed mainly by bivalves. Females preyed more heavily on anomuran crabs and isopods than males. Brachyuran crabs was the second prey item more consumed by males (Tab. 3)

Changes in the diet. Several patterns were found in the relationships between number of prey consumed with PCL, maturity stage, season and region for females (Tab. 4). The consumption of isopods and amphipods decreased with increasing PCL (Fig. 




FIGURE 3 I Cumulative prey curves as a function of sample size of Callorhinchus callorynchus for total individuals, males and for each group of females considered in the dietary analisis. Mean (continuous lines) $\pm \mathrm{SD}$ (dashed lines) are plotted.

4). On the other hand, the consumption of gastropods and anomuran crabs increased with increasing PCL (Fig. 4). Mature females preyed more heavily on brachyuran crabs than did immature females (Fig. 5). The consumption of brachyuran crabs and gastropods was higher in the cold season than in the warm season, and cumaceans were more consumed in the warm season than the cold season. The consumption of bivalves, anomuran crabs and cumaceans was affected by the region. C. callorynchus preyed more heavily on bivalves in the center region $\left(38^{\circ} \mathrm{S}\right)$ than in the north region $\left(36^{\circ}-38^{\circ} \mathrm{S}\right)$. The number of anomuran crabs and cumaceans consumed was higher in the north region than in the center region (Figs. 4, 5).

Models for bivalves, isopods and amphipods had a low $w$, therefore model averaging was computed. The averaged coefficient for bivalves was -0.248 (s.e. $=0.31)$ for the north 
TABLE 2 I Diet composition of Callorhinchus callorynchus off northern Argentina. \%N, percent number; \%PN, percent prey-specific number; $\% \mathrm{~W}$, percent weight; \%PW, percent prey-specific weight; \%FO, percent frequency of ocurrence; \%PSIRI, the prey-specific index of relative importance.

\begin{tabular}{|c|c|c|c|c|c|c|c|}
\hline PREY & & $\% \mathrm{~N}$ & $\%$ PN & $\% W$ & $\%$ PW & $\%$ FO & \%PSIRI \\
\hline \multicolumn{8}{|l|}{ MOLLUSCA } \\
\hline BIVALVIA & & 49.44 & 53.05 & 61.79 & 66.32 & 93.18 & 55.61 \\
\hline Unidentified Bivalvia & & 2.29 & 5.10 & 1.97 & 4.39 & 44.89 & 2.13 \\
\hline \multirow[t]{3}{*}{ Veneridae } & Amiantis purpurata & 16.73 & 33.46 & 18.19 & 36.38 & 50 & 17.46 \\
\hline & Tivela dentada & 1.16 & 14.57 & 1.88 & 23.64 & 7.95 & 1.52 \\
\hline & Transepitar americana & 0.97 & 28.37 & 1 & 29.28 & 3.41 & 0.98 \\
\hline \multirow[t]{2}{*}{ Mytilidae } & Mytilus edulis & 8.09 & 52.73 & 9.10 & 59.34 & 15.34 & 8.60 \\
\hline & Brachidontes rodriguezi & 2.36 & 14.87 & 5.40 & 33.96 & 15.91 & 3.88 \\
\hline Nuculanidae & Adrana electa & 1.46 & 8.02 & 2.03 & 11.19 & 18.18 & 1.75 \\
\hline Nuculidae & Ennucula puelcha & 1.38 & 24.22 & 1.09 & 19.28 & 5.68 & 1.23 \\
\hline \multirow[t]{3}{*}{ Mactridae } & Mactra isabelleana & 1.96 & 7.66 & 4.34 & 16.99 & 25.57 & 3.15 \\
\hline & Mactra marplatensis & 4.25 & 9.12 & 7.05 & 15.13 & 46.59 & 5.65 \\
\hline & Raeta plicatella & 0.01 & 1.82 & 0.03 & 4.52 & 0.57 & 0.02 \\
\hline Solenidae & Solen tehuelchus & 1.10 & 5.87 & 1.81 & 9.67 & 18.75 & 1.46 \\
\hline Corbulidae & Corbula patagonica & 5.94 & 23.23 & 6.88 & 26.92 & 25.56 & 6.41 \\
\hline Semelidae & Semelle spp. & 0.52 & 18.45 & 0.38 & 13.48 & 2.84 & 0.45 \\
\hline Cardiidae & Trachycardium muricatum & 0.09 & 1.75 & 0.08 & 1.55 & 5.11 & 0.08 \\
\hline Montacutidae & & 0.82 & 14.43 & 0.26 & 4.57 & 5.68 & 0.54 \\
\hline Glycymerididae & Glycymerididae longior & 0.06 & 2.02 & 0.17 & 6.01 & 2.84 & 0.11 \\
\hline \multirow[t]{2}{*}{ Tellinidae } & Ardeamya petitiana & 0.26 & 6.61 & 0.05 & 1.36 & 3.98 & 0.16 \\
\hline & Macoma brevifrons & 0.01 & 1.82 & 0.02 & 4.02 & 0.57 & 0.02 \\
\hline Pholadidae & Cyrtopleura lanceolata & 0.01 & 1.00 & $<0.01$ & 0.12 & 0.57 & $<0.01$ \\
\hline Pinnidae & Atriana seminuda & $<0.01$ & 0.67 & $<0.01$ & 0.15 & 0.57 & $<0.01$ \\
\hline Mesodesmatidae & Mesodesma mactroides & 0.01 & 1.33 & $<0.01$ & 0.04 & 0.57 & $<0.01$ \\
\hline \multicolumn{2}{|l|}{ GASTEROPODA } & 5.16 & 8.19 & 7.50 & 11.89 & 63.07 & 6.33 \\
\hline Unidentified Gasteropoda & & 3.02 & 4.92 & 5.28 & 8.60 & 61.36 & 4.15 \\
\hline Calliostomatidae & Photinulla spp. & 1.88 & 27.51 & 2.17 & 31.86 & 6.82 & 2.02 \\
\hline Crepidulidae & Crepidula argentina & 0.27 & 2.60 & 0.04 & 0.43 & 10.23 & 0.15 \\
\hline CRUSTACEA & & & & & & & \\
\hline BRACHYURA & & 8.15 & 13.04 & 13.10 & 20.96 & 62.5 & 10.63 \\
\hline Unidentified Brachyura & & 1.73 & 10.88 & 2.05 & 12.86 & 15.91 & 1.89 \\
\hline Actelecyclidae & Peltarion spinosulum & 1.75 & 44.05 & 1.84 & 46.22 & 3.98 & 1.79 \\
\hline Majidae & Libinia spinosa & 2.09 & 7.98 & 5.12 & 19.58 & 26.14 & 3.60 \\
\hline & Pyromaia spp. & 0.21 & 3.76 & 0.33 & 5.88 & 5.68 & 0.27 \\
\hline & Leuroclyclus tuberculata & 0.11 & 2.36 & 0.48 & 10.66 & 4.54 & 0.29 \\
\hline Epialtidae & Leucippa pentagona & 0.15 & 3.81 & 0.22 & 5.74 & 3.97 & 0.19 \\
\hline Beliidae & Corystoides chilensis & 0.68 & 4.01 & 1.81 & 10.62 & 17.04 & 1.25 \\
\hline Varunidae & Cyrtograpsus altimanus & 0.72 & 5.48 & 0.89 & 6.84 & 13.07 & 0.80 \\
\hline Platyxantidae & Platyxantidae crenulatus & 0.02 & 1.73 & $<0.01$ & 0.23 & 1.14 & 0.01 \\
\hline Pinnotheridae & Austinixa patagonesis & 0.58 & 6.42 & 0.17 & 1.92 & 9.09 & 0.38 \\
\hline & Pinnixa brevipollex & 0.01 & 1.37 & $<0.01$ & 0.06 & 0.57 & $<0.01$ \\
\hline & Pinnotheres garthi & 0.06 & 3.41 & 0.16 & 9.64 & 1.70 & 0.11 \\
\hline & Tumidotheres maculatus & 0.04 & 3.27 & 0.01 & 0.73 & 1.14 & 0.02 \\
\hline ANOMURA & & 7.29 & 13.50 & 5.15 & 9.53 & 53.98 & 6.22 \\
\hline Unidentified Anomura & & 0.80 & 4.14 & 0.22 & 1.16 & 19.32 & 0.51 \\
\hline Paguridae & Pagurus exilis & 3.93 & 12.13 & 3.07 & 9.47 & 32.39 & 3.50 \\
\hline & Pagurus criniticornis & 2.09 & 11.86 & 0.67 & 3.79 & 17.61 & 1.38 \\
\hline Diagonidae & Loxopagurus loxochelis & 0.45 & 6.66 & 0.94 & 13.76 & 6.82 & 0.70 \\
\hline Porcellanidae & Pachycheles laevidactylus & 0.01 & 2.04 & 0.05 & 8.33 & 0.57 & 0.03 \\
\hline Albuneidae & Blepharipoda doelloi & $<0.01$ & 0.67 & 0.20 & 35.44 & 0.57 & 0.10 \\
\hline ISOPODA & & 14.40 & 22.83 & 5.88 & 9.32 & 63.07 & 10.14 \\
\hline Unidentified Isopoda & & 0.34 & 2.30 & 0.03 & 0.22 & 14.77 & 0.18 \\
\hline Serolidae & Serolis marplatensis & 7.73 & 15.46 & 4.41 & 8.82 & 50 & 6.07 \\
\hline & Serolis bonaerensis & 0.13 & 2.92 & 0.01 & 0.23 & 4.54 & 0.07 \\
\hline Sphaeromatidae & Sphaeroma serratum & 5.83 & 13.32 & 1.37 & 3.14 & 43.75 & 3.60 \\
\hline Idoteidae & Idotea spp. & 0.36 & 3.18 & 0.05 & 0.41 & 11.36 & 0.20 \\
\hline & Jaeropsis dubia & $<0.01$ & 1 & $<0.01$ & 0.44 & 0.56 & $<0.01$ \\
\hline AMPHIPODA & & 7.28 & 15.83 & 1.84 & 4.00 & 46.02 & 4.56 \\
\hline Unidentified Amphipoda & & 0.30 & 2.95 & 0.03 & 0.29 & 10.23 & 0.16 \\
\hline Ampeliscidae & Ampelisca spp. & 6.69 & 18.68 & 1.79 & 5.01 & 35.79 & 4.24 \\
\hline Caprelidae & & 0.30 & 4.74 & 0.02 & 0.31 & 6.25 & 0.16 \\
\hline CUMACEA & & 4.27 & 9.39 & 1.24 & 2.74 & 45.45 & 2.76 \\
\hline Unidentified Cumacea & & 0.18 & 2.45 & 0.14 & 1.88 & 7.39 & 0.16 \\
\hline Diastylidae & & 2.48 & 7.38 & 0.39 & 1.15 & 33.52 & 1.43 \\
\hline Bodotriidae & & 1.61 & 8.10 & 0.72 & 3.61 & 19.89 & 1.16 \\
\hline CIRRIPEDIA & & 0.60 & 3.20 & 0.55 & 2.93 & 18.75 & 0.57 \\
\hline Balanidae & Balanus spp. & 0.60 & 3.20 & 0.55 & 2.93 & 18.75 & 0.57 \\
\hline TELEOSTEI & & 1.30 & 38.05 & 1.16 & 34.19 & 3.41 & 1.23 \\
\hline Unidentified Teleostei & & 1.30 & 38.05 & 1.16 & 34.19 & 3.41 & 1.23 \\
\hline POLYCHAETA & & 1.74 & 5.48 & 1.60 & 5.03 & 31.82 & 1.67 \\
\hline Lumbrineridae & & 0.91 & 4.34 & 0.73 & 3.51 & 21.02 & 0.82 \\
\hline Opheliidae & Travisia spp. & 0.54 & 19.32 & 0.83 & 29.33 & 2.84 & 0.69 \\
\hline Maldanidae & & 0.03 & 2.96 & $<0.01$ & 0.22 & 1.14 & 0.02 \\
\hline Tubos de poliquetos & & 0.25 & 2.31 & 0.03 & 0.25 & 10.79 & 0.14 \\
\hline ECHINODERMATA & & 0.03 & 4.76 & 0.01 & 1.78 & 0.57 & 0.02 \\
\hline Ophiuridae & & 0.03 & 4.76 & 0.01 & 1.78 & 0.57 & 0.02 \\
\hline BRYOZOA & & 0.07 & 1.42 & 0.01 & 0.13 & 5.11 & 0.04 \\
\hline SIPUNCULIDA & & 0.27 & 7.84 & 0.16 & 4.79 & 3.41 & 0.21 \\
\hline
\end{tabular}


TABLE 3 I Diet composition for females and males of Callorhinchus callorynchus off northern Argentina. \%PN: percent prey-specific number; \%PW: percent prey-specific weight; \%FO: percent frequency of occurrence; \%PSIRI: the prey-specific index of relative importance. A dash indicates that some categories of prey were not consumed by males.

\begin{tabular}{|c|c|c|c|c|c|c|c|c|}
\hline \multirow[b]{2}{*}{ Prey } & \multicolumn{2}{|c|}{$\%$ PN } & \multicolumn{2}{|c|}{$\%$ PW } & \multicolumn{2}{|c|}{$\%$ FO } & \multicolumn{2}{|c|}{ \%PSIRI } \\
\hline & Females & Males & Females & Males & Females & Males & Females & Males \\
\hline Bivalvia & 50.94 & 67.44 & 65.29 & 73.31 & 94.08 & 87.5 & 54.67 & 61.58 \\
\hline Gasteropoda & 8.28 & 6.25 & 12.21 & 5.12 & 69.74 & 20.83 & 7.14 & 1.18 \\
\hline Brachyura & 11.12 & 28.74 & 18.74 & 39.10 & 64.47 & 50 & 9.62 & 16.96 \\
\hline Anomura & 12.93 & 23.75 & 9.73 & 5.88 & 59.21 & 20.83 & 6.71 & 3.09 \\
\hline Isopoda & 22.24 & 38.49 & 9.02 & 17.42 & 70.39 & 16.67 & 11.00 & 4.66 \\
\hline Amphipoda & 15.92 & 14.09 & 4.14 & 1.41 & 50.66 & 16.67 & 5.08 & 1.29 \\
\hline Cumacea & 9.41 & 8.56 & 2.80 & 0.31 & 51.31 & 8.33 & 3.13 & 0.37 \\
\hline Cirripedia & 3.24 & 2.04 & 3.01 & 0.11 & 21.05 & 4.17 & 0.65 & 0.04 \\
\hline Teleostei & 20.00 & 41.67 & 32.67 & 34.50 & 0.66 & 20.83 & 0.17 & 7.93 \\
\hline Polychaeta & 4.74 & 25.5 & 3.59 & 43.78 & 35.53 & 8.33 & 1.48 & 2.89 \\
\hline Equinodermata & 4.76 & & 1.78 & & 0.66 & & 0.02 & \\
\hline Bryozoa & 1.42 & & 0.13 & & 5.92 & & 0.04 & \\
\hline Sipunculida & 7.84 & & 4.79 & & 3.95 & & 0.04 & \\
\hline
\end{tabular}

TABLE 4 I Best models explaining the consumption in number of the main prey categories of Callorhinchus callorynchus off northern Argentina. PCL: precaudal length; AIC: Akaike Information criterion; w: Akaike weights. The coefficients of the models are relative to immature individuals, center region and warm season. Standard error in parentheses.

\begin{tabular}{r|c|c|c|}
\hline Prey categories & Intercept & Coefficient & AIC \\
\hline Bivalvia & $3.56(0.12)$ & $-0.49(0.28)$ north & 1286.1 \\
\hline Gasteropoda & $-4.55(1.13)$ & $0.01(<0.01)$ PCL $+0.76(0.22)$ cold & 499.8 \\
\hline Brachyura & $0.19(0.2)$ & $0.59(0.24)$ mature $+0.58(0.23)$ cold & 0.21 \\
\hline Anomura & $-3.68(1.36)$ & $0.01(<0.01)$ PCL $+0.91(0.34)$ north & 0.58 \\
\hline Isopoda & $5.02(1.26)$ & $-0.01(0.002)$ PCL & 0.57 \\
\hline Amphipoda & $7.07(1.87)$ & $-0.01(0.004)$ PCL & 925.5 \\
\hline Cumacea & $1.17(0.19)$ & $-1.36(0,32)$ cold $+1.59(0.37)$ north & 0.42 \\
\hline
\end{tabular}



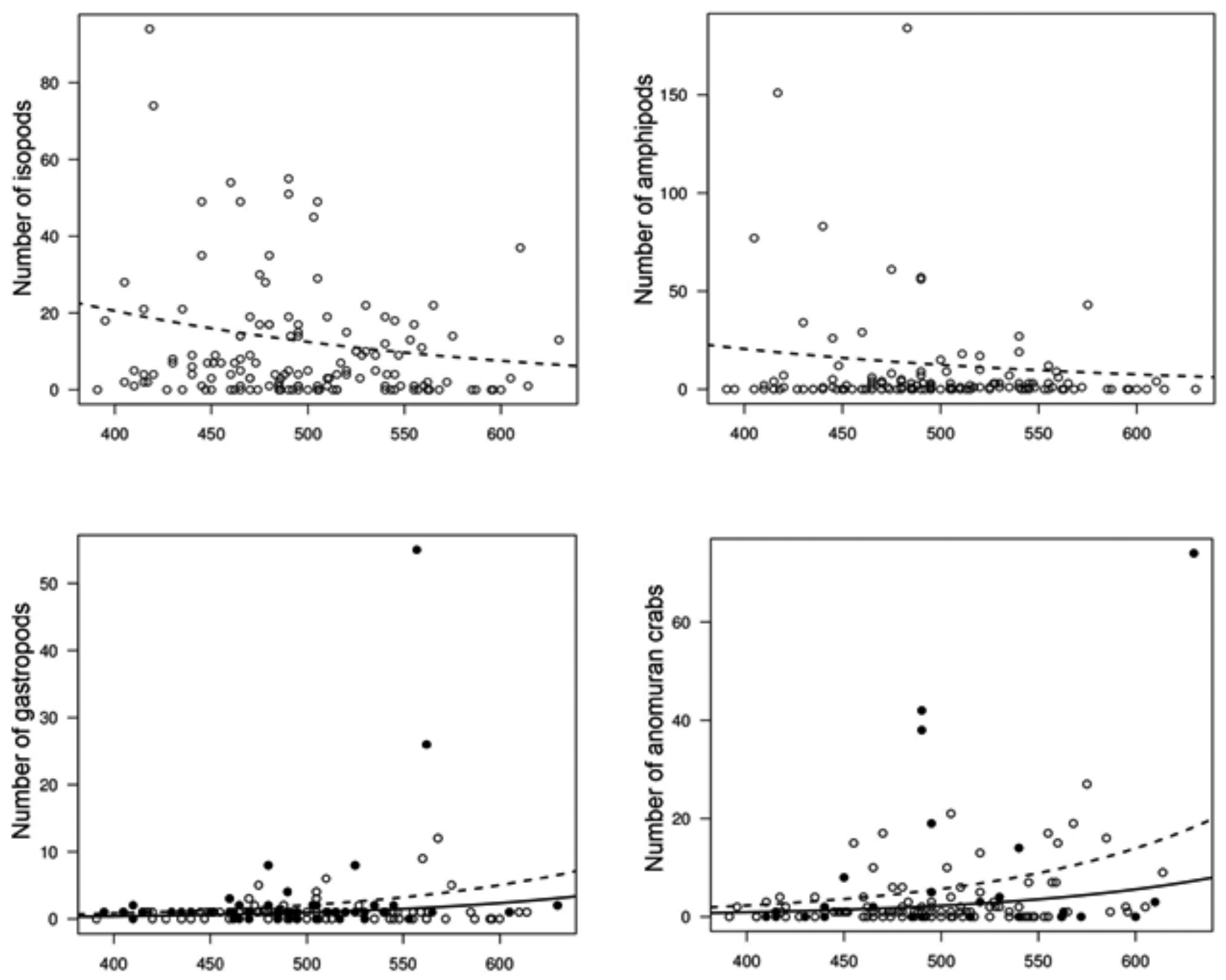

Precaudal lenght $(\mathrm{mm})$

FIGURE 4 I Changes in consumption of isopods, amphipods, gastropods and anomuran crabs with body size, season and region of Callorhinchus callorynchus females estimated by generalized linear models. In gastropods: cold season with dashed lines and open circles; warm season with solid lines and solid circles. In anomuran crabs: north region with dashed lines and open circles; center region with solid lines and solid circles.

region $(w=0.52)$. For isopods and amphipods the averaged coefficients were -0.003 (s.e. $=0.003$ ) and -0.001 (s.e. $=0.004$ ) for PCL with a $w$ of 0.60 and 0.88 , respectively.

No relationship between PCL of C. callorynchus and CW of brachyuran crabs was found. However, as significant relationship between predator size and size of bivalves was found. As PCL of C. callorynchus increased, minimum, medium and maximun VW of bivalves increased (slopes of 5, 50 and 95\% quantile regressions $=0.010,0.022,0.019$, respectively; $\mathrm{p}$ < 0.01) (Fig. 6). 

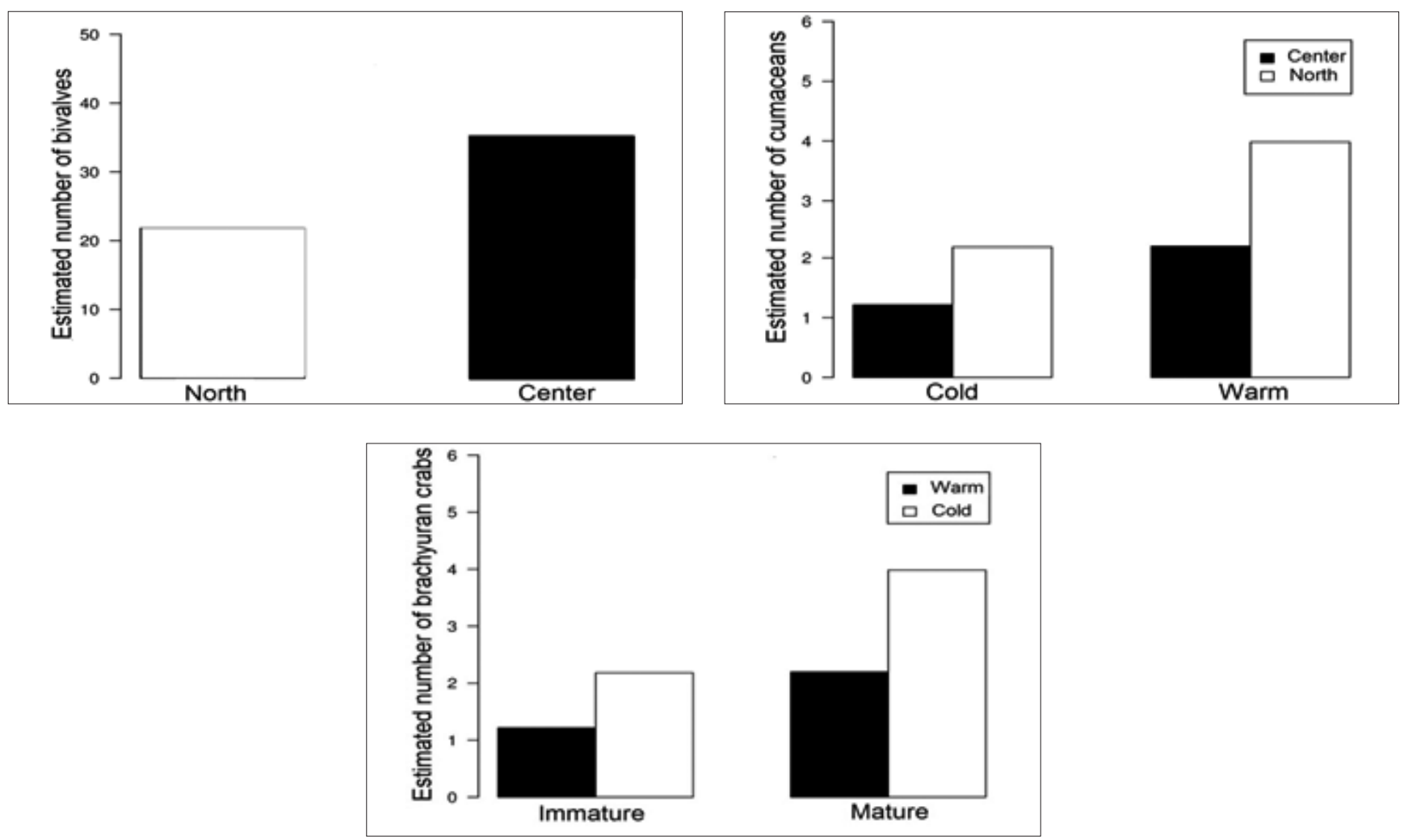

FIGURE 5 I Changes in consumption of bivalves, cumaceans and brachyuran crabs with region, season and maturity stage of Callorhinchus callorynchus females estimated by generalized linear models.

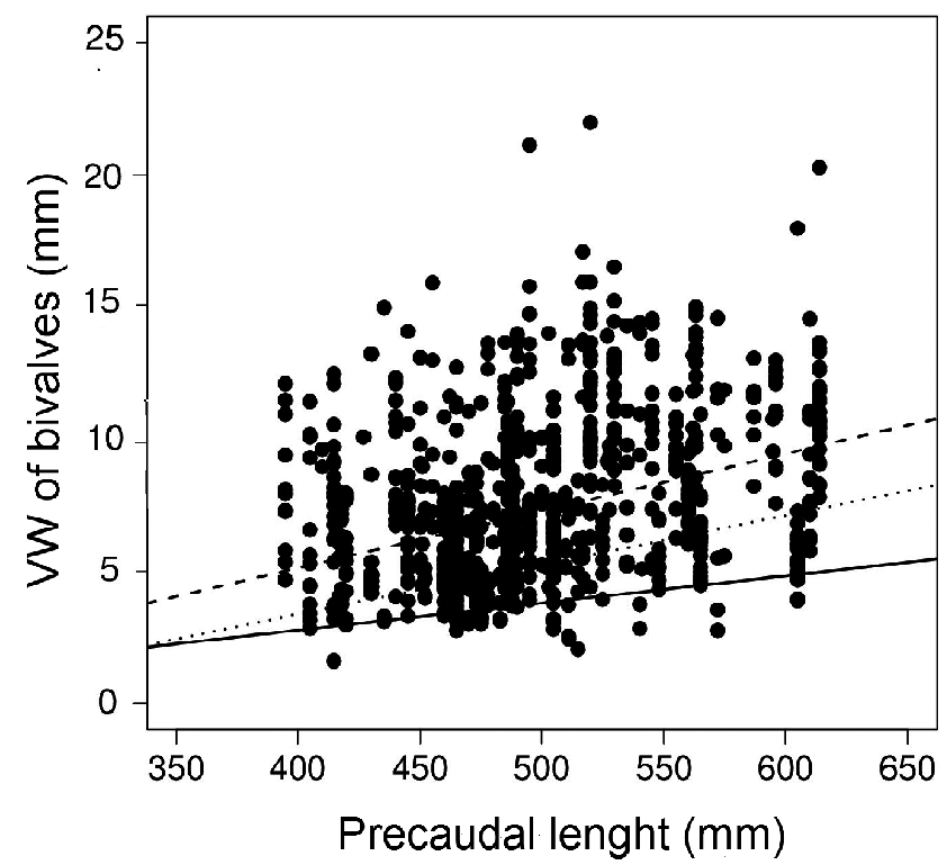

FIGURE 6 I Relationship between valve width (VW) of bivalves and precaudal lenght of Callorhinchus callorynchus. The solid, dashed and dotted lines are 5\%, 50\% and 95\% quantile regressions, respectively. 
Trophic level. The mean trophic position was 3.19 (standard deviation $=0.01$ ), indicating that C. callorynchus is a secondary consumer throughout the entire study area.

\section{DISCUSSION}

The diet of C. callorynchus consists mainly of bivalves, followed by brachyuran crabs, isopods, and other benthic invertebrates, which implies that this species has benthic feeding habits. Further, C. callorynchus females showed changes in the diet composition with increasing body size and also between seasons and regions.

A previous study conducted in the San Matías Gulf, northen Patagonia (41 $30^{\circ} \mathrm{S}$ $64^{\circ} 15^{\prime} \mathrm{W}$ ), found that bivalves were the main prey consumed by C.callorynchus, followed by polychaetes, decapods and stomatopods (Di Giácomo, Perier, 1996). However, the main species of bivalve consumed were different between studies. The most important species of bivalves observed by Di Giácomo, Perier (1996) were the scallop Zygochlamys patagonica, and the clams Ennucula puelcha and Pitar rostratus. In our study, the clams Amiantis purpurata, Mytilus edulis, Corbula patagonica and Mactra marplatensis were the most consumed bivalves. This difference in consumption of bivalves may be associated with regional and bathymetric differences in prey availability, because the results of Di Giácomo, Perier (1996) reflected the diet of samples taken in the San Matías Gulf in depths between $20 \mathrm{~m}$ and $130 \mathrm{~m}$, whereas the samples in our study were obtained exclusively in coastal areas ( $<50 \mathrm{~m}$ depths). Our results also agree with Rios, Pereira (1986); they observed that in individuals captured off Uruguay and northern Argentina $\left(34^{\circ} 38^{\prime} \mathrm{S}-54^{\circ} 53^{\prime} \mathrm{W} 34^{\circ} 36^{\prime} \mathrm{S}-57^{\circ} 53^{\prime} \mathrm{W}\right)$ between 10 and $80 \mathrm{~m}$ depth the most important prey were bivalves.

In Atlantic waters the diet of C. callorynchus is mainly dominated by bivalves, however, this observation is not consistent in Pacific localities. For example, in coastal waters off San Antonio (Molina et al., 1980) and off Puerto Montt (Bahamonde, 1950), Chile, the diet composition of C. callorynchus was dominated mainly by decapod crustaceans. These differences in the overall observation of diet composition between Atlantic and Pacific waters may be due possibly to several reasons: different prey availability in benthic communities, different regional interaction between potential competitors in each marine community, period of time in which these studies were conduced, and that the two Pacific studies were conduced off central Chile.

Callorhinchus callorynchus, in Atlantic waters, showed a diet similar to another Callorhinchidae species. Callorhinchus capensis off Velddrif Harbour, South Africa, has a high frequency of bivalves in its diet (e.g., Mytilus galloprovincialis and Choromytilus merdionalis) (Nibam, 2011). On the other hand, in the northeastern Atlantic, other chimaeroid species of the families Chimaeridae (Chimaera monstrosa and Hydrolagus mirabilis) and Rhinochimaeridae (Harriotta raleighana) have a diverse diet based on benthic invertebrates. These species feed mainly on crustaceans, polychaetes, echinoderms and anemones (Mauchline, Gordon, 1983). In the same way, on the continental slope off southern Portugal and in the Eastern Mediterranean, the rabbitfish C. monstrosa presents a diet composed mainly by crustaceans (i.e., amphipods and crabs), followed by polychaetes and molluscs (Moura et al., 2005; Eronat, 2016). The biomass and distribution of the benthic fauna varies with depth (Witman, Roy, 2009). Therefore, 
these differences in the diet among chimaeroid families could be related to differences in the depth distribution range: Callorhinchidae species occurs in coastal regions, whereas Chimaeridae and Rhinochimaeridae species occur mainly in deep waters.

Off northern Argentina C. callorynchus consumes a wide variety of benthic organisms, however, its diet was composed mostly by hard prey (e.g., bivalves, gastropods, brachyuran and anomuran crabs). This feeding habit may be related to the development of tooth plates of the mouth apparatus which could be the most relevant characteristic associated with the crushing of the hard prey, favoring feeding habits suited for durophagy (Di Giácomo, Perier, 1996; Summers, 2000; Summers et al., 2003). Furthermore, the consumption of the infaunal prey suggests that C. callorynchus could dig into the bottom in search of prey. An important result to note is the high consumption of the purple clam Amiantis purpurata. This infaunal bivalve is common in the coastal sandy bottom of the Southwest Atlantic (Penchaszadeh et al., 2006). There is evidence that this species is an important food source for a number of chondrichthyan species in shallow coastal waters (e.g., Discopyge tschudii, Spath et al., 2012; Myliobatis spp., Molina, López Cazorla, 2015). However, the extent of its contribution to the food web is still unknown.

Predator roles in marine communities can be influenced by many factors, such as prey abundance, body size and reproductive condition (Wetherbee, Cortés, 2004). As a result, ontogenetic, regional and/or seasonal changes in the dietary composition can occur. Ontogenetic diet shifts are a phenomenon widely observed in many chondrichthyan species off northern Argentina (Lucifora et al., 2009; Barbini, Lucifora, 2011; 2012; Belleggia et al., 2012; Spath et al., 2012; Ruocco, Lucifora, 2016). In the same way, C. callorynchus females showed shifts in its diet composition: small individuals consumed amphipods and isopods, but large individuals preyed on gastropods and brachyuran and anomuran crabs. A possible explanation for these dietary shifts can be a combination of an improved ability to capture larger prey and a change in the reproductive condition of large individuals. As body size increases, individuals can modify their abilities associated with the feeding, such as gape size, bite force, handling and suction force (Tanaka, 1973; Capapé, 1976; Hernandez, Motta, 1997; Scharf et al., 2000; Carrol et al., 2004; Huber, Motta, 2004; Lowry, Motta, 2008; El Kamel-Moutalibi et al., 2013). On the other hand, an increase in the metabolic requirements of mature females may also contribute to generate ontogenetic dietary shifts. A similar observation was found in San Matías Gulf, where mature individuals of C. callorynchus preyed more heavily on crabs than immature individuals (Di Giácomo, Perier, 1996).

The diet composition of C. callorynchus females varied seasonally and regionally. Callorhinchus callorynchus consumed more brachyuran crabs and gastropods in the cold season, and feed on cumaceans in the warm season. Information on seasonal variability of the abundance of benthic invertebrates consumed by C. callorynchus in the study area is not available and further studies are needed. However, the seasonal variability could be attributed to fluctuations in the distribution and abundance of the prey (Muto et al., 2001). This finding for females of C. callorynchus has been suggested for other species of chondrichthyans in the same area (e.g., Psammobatis extenta, Braccini, Perez, 2005; P. bergi, San Martín et al., 2007; Zapteryx brevirostris, Barbini, Lucifora, 2011; Barbini et al., 2011; Rioraja agassizii, Atlantoraja castelnaui, Barbini, Lucifora, 2012).

The regional variability is characterized by a higher consumption of bivalves in the center region and a higher consumption of anomuran crabs and cumaceans in 
the north region. Differences in richness and abundance of the benthic community between regions could explain this variability. The north area is strongly influenced by the Río de la Plata estuary: bottom type, salinity and the presence of a turbidity front are considered the main variables structuring the benthic community of this area (Giberto et al., 2004). Consequently, the spectrum of available prey could be different between these regions. These results indicate that C. callorynchus is a plastic and versatile predator, adapting its feeding habits in response to seasonal and regional changes.

Our results show that as the size of C. callorynchus increases, the size of consumed bivalves does too. An increase of prey size consumed is generally attributed to ontogenic mouth size increase (Karachle, Stergiou, 2011). The selection of small prey by small individuals may be the results of morphological constraints, as mouth gape or the development of the structures involved in the feeding (i.e., tooth plates of the upper and lower jaws) (Di Giácomo, Perier, 1996; Scharf et al., 2000; Karpouzi, Stergiou, 2003). The pattern found here may be related to the crushing power of the mouth of large individuals, which could be higher than of the mouth of small individuals (Juanes et al., 2002). Bivalve shell's strength is typically correlated with its size (Zuschin et al., 2003; Lowry, Motta, 2007; Kolman, Huber, 2009). Thus, small individuals of C. callorynchus may be unable to both handle and crush hard-shelled prey.

The trophic level of C. callorynchus indicates that it is a secondary consumer in the northern Argentina coastal ecosystems. This constitutes the first trophic level estimation for a member of the family Callorhinchidae. Eronat (2016) estimated the trophic levels of Chimaera monstrosa off Sigacik Bay, Eastern Mediterranean, with values similar to those reported in this study. The Shortose eagle ray Myliobatis ridens (Myliobatiformes) is a chondrichthyans with feeding habits similar to C. callorynchus in the same area of study (Ruocco, Lucifora, 2016). It is known that some benthic Myliobatiformes affect the species turnover of benthic communities by disrupting the structure of the bottom and preying on benthic invertebrates (VanBlaricom, 1982; Thrush et al., 1994). Hence, C. callorynchus being a secondary consumer that feeds on benthic prey, could play an important role structuring benthic communities.

In conclusion, this study provides valuable information on the feeding habits of an important predator in the coastal waters from off northern Argentina. Our results show that this holocephalan has a strong predatory interaction with the benthic community, since its diet was composed mainly of benthic prey (i.e., bivalves, brachyuran crabs and isopods). In addition, this study fills gaps in our knowledge about his biology in this area. However, to deepen understanding of the feeding habits of C. callorynchus in this area, future research should consider a greater number of juvenile individuals $(<300$ $\mathrm{mm}, \mathrm{PCL}$ ) and adult males (> $500 \mathrm{~mm}, \mathrm{PCL})$.

\section{ACKNOWLEDGMENTS}

We are grateful to artisanal fishermen (Martín, Julio, Jose and Hector) for sample collection. We thank C. Bass and L. Ferrero for help in the indetification of prey, C. Estupiñán-Montaño and S. A. Briones-Hernández for their suggestions in the calculation of the prey-specific index of relative importance, and L. O. Lucifora and E. E. Di Giácomo for critical reading of the manuscript. We also wish to extend our thanks 
to the anonymous reviewers for comments that greatly improved the manuscript. J. M. Roman and M. A. Chierichetti were supported by scholarships from CIC and CONICET (Argentina), respectively.

\section{REFERENCES}

- Alarcón C, Cubillos LA, Acuña E. Lengthbased growth, maturity and natural mortality of the cockfish Callorhinchus callorhynchus (Linnaeus, 1758) off Coquimbo, Chile. Environ Biol Fishes. 2011; 92(1):65-78. https://doi.org/10.1007/s10641011-9816-0

- Anderson DR, Burnham KP, Thompson WL. Null hypothesis testing: problems, prevalence, and an alternative. J Wildl Manage. 2000; 64(4):912-23. https://doi. org/10.2307/3803199

- Bahamonde N. Alimentación del pejegallo (Callorynchus callorynchus). Investigaciones Zoológicas Chilenas. 1950; 1:4-6. Available from: http://www. memoriachilena.gob

- Barbini SA, Lucifora LO. Feeding habits of the rio skate, Rioraja agassizi (Chondrichthyes: Rajidae), from off Uruguay and north Argentina. J Mar Biol Assoc U K. 2011; 91(6):1175-84. https://doi. org/10.1017/S0025315410001529

- Barbini SA, Lucifora LO. Feeding habits of a large endangered skate from the Southwest Atlantic: the spotback skate Atlantoraja castelnaui. Mar Freshw Res. 2012; 63(2):180-88. https://doi.org/10.1071/ MF11170

- Barbini SA, Lucifora LO. Diet composition and feeding habits of the eyespot skate, Atlantoraja cyclophora (Elasmobranchii: Arhynchobatidae), off Uruguay and northern Argentina. Neotrop Ichthyol. 2016; 14(3):e160032. http://dx.doi.org/10.1590/19820224-20160032

- Barbini SA, Lucifora LO, Hozbor NM. Feeding habits and habitat selectivity of the shortnose guitarrish, Zapteryx brevirostris (Chondrichthyes, Rhinobatidae), off north Argentina and Uruguay. Mar Biol Res. 2011; 7(4):365-77. https://doi.org/10.1080/17451000.2010.51 5229

- Belleggia M, Figueroa DE, Sánchez F, Bremec C. The feeding ecology of Mustellus schmitti in the southwestern Atlantic: geographic variations and dietary shifts. Environ Biol Fishes. 2012; 95:99-114. https://doi.org/10.1007/s10641-011-9874-3
- Bernasconi JF, Perier MR, Di Giácomo EE. Standardized catch rate of cockfish, Callorhinchus callorynchus, in a bottom trawl fishery of Patagonia: Is it possible its use a predictor of abundance trend? Braz J Oceanogr. 2015a; 63(2):147-60. https://doi. org/10.1590/S1679-87592015093606302

- Bernasconi JF, Cubillos L, Acuña E, Perier R, Di Giácomo EE. Crecimiento, madurez y mortalidad del pez gallo, Callorhinchus callorynchus, en el Golfo San Matías, Patagonia norte, Argentina. Rev Biol Mar Oceanogr. 2015b; 50(2):28398. http://dx.doi.org/10.4067/S071819572015000300007

- Braccini JM, Perez JE. Feeding habits of the sandskate Psammobatis extenta (Garman, 1913): sources of variation in dietary composition. Mar Freshw Res. 2005; 56(4):395-403. https://doi.org/10.1071/ MF04205

- Brown SC, Bizzarro JJ, Cailliet GM, Ebert DA. Breaking with tradition: redefining measures for diet description with a case study of the Aleutian skate Bathyraja aleutica (Gilbert 1896). Environ Biol Fishes. 2012; 95:3-20. https://doi.org/10.1007/ s10641-011-9959-Z

- Capapé C. Étude du régime alimentaire de l' Aigle de mer, Myliobatis Aquila (L., 1758) des côtes tunisiennes. J Cons int Explo Mer. 1976; 37(1):29-35. https://doi.org/10.1093/ icesjms/37.1.29

- Carroll GM, Wainwrigh PC, Huskey SH, Collar DC, Turingan RG. Morphology predicts suction feeding performance in centrarchid fishes. J Exp Biol. 2004; 207:3873-81. https://doi.org/10.1242/ jeb.01227

- Cedrola P, Bovcon N, Bruno C, Bustamante C, Caille G, Calvo S et al. La pesca deportiva de condrictios en el Mar Argentino. In: Wöhler OC, Cedrola $\mathrm{P}$, Cousseau MB, editors. Contribuciones sobre la biología, pesca y comercialización de tiburones en la Argentina. Aportes para la elaboración del Plan de Acción Nacional. Buenos Aires: Consejo Federal Pesquero; 2011. p.185-92. 
- Chierichetti MA, Scenna LB, Di Giácomo EE, Ondarza PM, Figueroa DE, Miglioranza KSB. Reproductive biology of the cockfish, Callorhinchus callorynchus (Chondrichthyes: Callorhinchidae), in coastal waters of the northern Argentinean Sea. Neotrop Ichthyol. 2017; 15(2):e160137. https://doi.org/10.1590/1982-0224-20160137

- Cochrane KL. The use of scientific information in the design of management strategies. FAO Fish Tech Pap. 2002; 424:95-130. Available from: http://www. fao.org/3/y3427e/y3427e07.htm

- Consejo Federal Pesquero. Plan de acción nacional para la conservación y el manejo de condrictios (tiburones, rayas y quimeras) en la República Argentina. Buenos Aires: Subsecretaría de Pesca y Acuicultura, Secretaría de Ambiente y Desarrollo Sustentable y Ministerio de Relaciones Exteriores, Comercio Internacional y Culto; 2009. Available from: http://www.fao.org/tempref/FI/ DOCUMENT/IPOAS/national/argentina/ NPOA_sharks.pdf

- Cortés E. Standarized diet compositions and trophic levels in sharks. ICES J Mar Sci. 1999; 56(5):707-17. https://doi.org/10.1006/ jmsc.1999.0489

- Cousseau MB, Perrotta RG. Peces marinos de Argentina: biología, distribución, pesca. 4th ed. Mar del Plata: INIDEP; 2013.

- Crawley MJ, editor. Statistics: an Introduction Using R. Wiley, Chichester: John Willey and Sons; 2005.

- Dagit DD, Chiaramonte GE, Romero M, Di Giácomo EE, Acuña E. Callorhinchus callorynchus. In: IUCN Red list of Threatened Species. Version 2012.2 [Internet]. 2007. Available from: http:// www.iucnredlist.org/details/63107/0

- Didier DA. Phylogeny and classification of extant Holocephali. In: Carrier JC, Musick JA, Heithaus MR, editors. Biology of sharks and their relatives. Boca Raton: CRC Press; 2004. p.115-35.

- Di Giácomo EE. Contribución al estudio biológico-pesquero del pez gallo, Callorhynchus callorhynchus (Linné 1758), Berg 1895, en el Golfo San Matías. [PhD Thesis]. La Plata (PBA): Universidad Nacional de La Plata; 1990. Available from: https://www.oceandocs.org

- Di Giácomo EE. Distribución de la población del pez gallo (Callorhynchus callorhynchus) en el Golfo de San Matías, Argentina. Frente Marítimo. 1992; 12(A):113-18. Available from: http://www. ctmfm.org/upload
- Di Giácomo EE, Parma AM, Orensaz JM. Food consumption by the cock fish Callorhynchus callorynchus (Holocephali: Callorhynchidae), from Patagonia (Argentina). Environ Biol Fishes. 1994; 40:199-211. https://doi.org/10.1007/ BF00002546

- Di Giácomo EE, Perier MR. Reproductive biology of the cockfish Callorhynchus callorhynchus (Holocephali: Callorhynchidae) in Patagonian waters (Argentina). Fish Bull. 1994; 92:531-39.

- Di Giácomo EE, Perier MR. Feeding habits of cockfish, Callorhinchus callorhynchus (Holocephali: Callorhynchidae), in Patagonian waters (Argentina). Mar Freshw Res. 1996; 47(6):801-08. https://doi. org/10.1071/MF9960801

- Ebert DA, Bizarro JJ. Standardized diet compositions and trophic levels of skates (Chondrichthyes: Rajiformes: Rajoidei). Environ Biol Fishes. 2007; 80:221-37. https://doi.org/10.1007/978-1-4020-9703-4_8

- El Kamel-Moutalibi O, MNasri N, Boumaïza M, Reynaud C, Capapé C. Diet of common torpedo Torpedo torpedo (Chondrichthyes: Torpedinidae) from the Lagoon of Bizerte (northeastern Tunisia, central Mediterranean). Cah Biol Mar. 2013; 54:209-20. https://doi.org/10.21411/ CBM.A.2A072741

- Eronat, EGT. Feeding ecology and Trophic level of Chimaera monstrosa Linnaeus, 1978 (Holocephali: Chimaeridae) in the Eastern Mediterranean. Zool Middle East. 2016; 62(1):51-7. https://doi.org/10.1080/09 397140.2015 .1132560

- Ferry LA, Cailliet GM. Sample size and data analysis: are we characterizing and comparing diet properly? In: MacKinlay D, Shearer K, editors. Feeding Ecology and Nutrition in Fish: Proceedings of the Symposium on the Feeding Ecology and Nutrition in Fish. San Francisco: American Fisheries Society; 1996. p.71-80.

- Franklin AB, Shenk TM, Anderson DR, Burnham KP. Modeling in natural resources management: development, interpretation, and application. In: Shenk TM, Franklin AB, editors. Statistical model selection: an alternative to null hypothesis testing. Washington: Island Press; 2001. p.75-90.

- Giberto DA, Bremec CS, Acha EM, Mianzan H. Large-scale spatial patterns of benthic assemblages in the SW Atlantic: The Río de la Plata estuary and adjacent shelf waters. Estuar Coast Shelf Sci. 2004; 61(1):1-13. https://doi.org/10.1016/j. ecss.2004.03.015 
- Guerrero RA, Piola AR. Masas de agua en la Plataforma Continental. In: Boschi EE, editor. El Mar Argentino y sus recursos pesqueros. Tomo 1. Antecedentes históricos de las exploraciones en el mar y las características ambientales. Mar del Plata: INIDEP; 1997. p.107-18. Available from: https://www.oceandocs.org/ handle/1834/1703

- Hernandez LP, Motta PJ. Trophic consequences of differential performance: ontogeny of oral jaw crushing performance in the sheepshead, Archosargus probatocephalus (Teleostei: Sparidae). J Zool Lond. 1997; 243:737-56. https://doi. org/10.1111/j.1469-7998.1997.tb01973.x

- Huber DR, Motta PJ. Comparative analysis of methods for determining bite force in the spiny dogfish Squalus acanthias. J Exp Zool A Comp Exp Biol. 2004; 301(1):26-37. https://doi.org/10.1002/jez.a.20003

- Johnson JB, Omland KS. Model selection in ecology and evolution. Trend Ecol Evol. 2004; 19(2):101-08. https://doi. org/10.1016/j.tree.2003.10.013

- Juanes F, Buckel JA, Scharf FS. Feeding ecology of piscivorous fishes. In: Hart PJB, Reynolds JD, editors. Handbook of fish biology and fisheries. Fish Biology. Vol. I. London: Blackwell Publishing; 2002. p.267-83.

- Karachle PK, Stergiou KI. Mouth allometry and feeding habits of some Mediterranean fishes. Acta Ichthyol Piscat. 2011; 41(4):265-75. https://doi.org/10.3750/ AIP2011.41.4.02

- Karpouzi VS, Stergiuo KI. The relationships between size and shape and body length for 18 species of marine fishes and their trophic implications. J Fish Biol. 2003; 62(6):1353-65. https://doi. org/10.1046/j.1095-8649.2003.00118.x

- Kolman M, Huber D. Scaling of feeding biomechanics in the horn shark Heterodontus francisci: ontogenetic constraints on durophagy. Zoology. 2009; 112(5):351-61. https://doi.org/10.1016/j. zool.2008.11.002

- López HL, San Román NA, Di Giácomo EE. On the South Atlantic distribution of Callorhinchus callorhynchus (Holocephali: Callorhynchidae). J Appl Ichthyol. 2000; 16(1):39. https://doi.org/10.1046/j.14390426.2000.00142.x

- Lowry D, Motta PJ. Ontogeny of feeding behavior and cranial morphology in the whitespotted bammooshark Chiloscyllium plagiosum. Mar Biol. 2007; 151(6):2013-23. https://doi.org/10.1007/s00227-007-0642-z
- Lowry D, Motta PJ. Relative importance of growth and behaviour to elasmobranch suction-feeding performance over early ontogeny. J R Soc Interface. 2008; 5:641-52. https://doi.org/10.1098/rsif.2007.1189

- Lucas AJ, Guerrero RA, Mianzán HW, Acha EM, Lasta CA. Coastal oceanographic regimes of the Northen Argentine Continental Shelf $\left(34^{\circ}-43^{\circ} \mathrm{S}\right)$. Estuar Coast Shelf S. 2005; 65(3):405-20. https://doi. org/10.1016/j.ecss.2005.06.015

- Lucifora LO, García VB, Menni RC, Escalante AH. Food habits, selectivity, and foraging modes of the school shark Galeorhinus galeus. Mar Ecol Prog Ser. 2006; 315:259-70. https://doi.org/10.3354/ meps315259

- Lucifora LO, García VB, Escalante AH. How can the feeding habits of the sand tiger shark influence the success of conservation programs? Anim Conserv. 2009; 12(4): 291-301. https://doi. org/10.1111/j.1469-1795.2009.00247.x

- Lucifora LO, García VB, Menni RC, Worm B. Spatial patterns in the diversity of sharks, rays, and chimaeras (Chondrichthyes) in the Southwest Atlantic. Biodivers Conserv. 2012; 21:40719. https://doi.org/10.1007/s10531-011-01897

- Massa AM, Lucifora LO, Hozbor NM. Condrictios de las regiones costeras bonaerenses y uruguaya. In: Sánchez RP, Bezzi SI, editors. El Mar Argentino y sus recursos pesqueros. Tomo 4. Los peces marinos de interés pesquero. Caracterización biológica y evaluación del estado de explotación. Mar del Plata: INIDEP; 2004. p.85-99.

- Mauchline J, Gordon JDM. Diets of the shark and chimaeroids of the Rockall Trough, northeastern Atlantic Ocean. Mar Biol. 1983; 75:269-78. https://doi. org/10.1007/BF00406012

- Molina JM, López Cazorla A. Biology of Myliobatis goodei (Springer, 1939), a widely distributed Eagle ray, caught in northern Patagonia. J Sea Res. 2015; 95:106-14. http://dx.doi.org/10.1016/j. seares.2014.09.006

- Molina CD, Elgueta HC, Osorio H. Contenido gastrico de Callorhynchus callorhynchus (Linnaeus, 1758) capturado entre Algarrobo y Pupuya (Chile) (Holocephali, Challorhynchidae). Museo Nacional de Historia Natural Noticiario Mensual (Santiago, Chile). 1980; 279-80:410. Available from: http://publicaciones. mnhn.gob.cl/668/w3-article-66431.html 
- Moura T, Figuereido I, Bordalo-Machado P, Serrado Gordo L. Feeding habits of Chimaera monstrosa L. (Chimaeridae) in relation to the ontogenetic development on the southern Portuguese continental slope. Mar Biol Res. 2005; 1(2):118-26. https://doi. org/10.1080/17451000510019079

- Muto EY, Soares LSH, Goiten R. Food resource utilization of the skate Rioraja agassizi and Psammobatis extenta on the continental shelf of Ubatuba, south-eastern Brazil. Revista Brasileira de Biologia. 2001; 61(2):217-38. https://doi.org/10.1590/S003471082001000200005

- Nibam AH. Reproductive biology and diet of the St. Joseph (Callorhinchus capensis) in South Africa. [PhD Thesis]. Cape Town (ZA): University of Cape Town; 2011. Available from: http://hdl.handle. net/11427/10791

- Penchaszadeh PE, Arrighetti F, Cledón M, Livore JP, Botto F, Iribarne 00. Bivalve Contribution to shallow Sandy bottom food web off Mar del Plata (Argentina): inference from stomach contents and stable isotope Analysis. J Shellfish Res. 2006; 25:51-54. https://doi.org/10.2983/0730 8000(2006)25[51:BCTSSB]2.0.CO;2

- R Development Core Team. R: A language and environment for statistical computing. $\mathrm{R}$ Foundation for Statistical Computing; 2012. Available from: http://www.R-project.org

- Rios EC, Pereira J. Pez-elefante, un pez malacófago. Comun Soc Malacol Urug. 1986; 6:427-28.

- Ruocco NL, Lucifora LO. Ecological singularity of temperate mesopredatory myliobatoid rays (Chondrichthyes: Myliobatiformes). Mar Freshw Res. 2016; 68(6):1098-111. https://doi.org/10.1071/ MF15469

- San Martín MJ, Braccini JM, Tamini LL, Perez JE, Chiaramote GE. Temporal and sexual effects in the feeding ecology of the marbled sandskate Psammobatis bergi Marini, 1932. Mar Biol. 2007; 151:505-13. https://doi.org/10.1007/s00227-006-0499-6

- Scharf FS, Juanes F, Sutherland M. Inferring ecological relationships from the edges of scatter diagrams: comparison of regression techniques. Ecology. 1998; 79(2):448-60. https://doi.org/10.1890/00129658(1998)079[0448:IERFTE]2.0.CO;2

- Scharf FS, Juanes F, Rountree RA. Predator size-prey size relationships of marine fish predators: interspecific variation and effects of ontogeny and body size trophic-niche breadth. Mar Ecol Progr Ser. 2000; 208:229-48. https://doi. org/10.3354/meps208229
- Spath MC, Barbini SA, Figueroa DE. Feeding habits of the apron ray, Discopyge tschudii (Elasmobranchii: Narcinidade), from off Uruguay and northern Argentina. J Mar Biol Assoc U K. 2012; 93(2):291-97. https://doi.org/10.1017/S0025315412000665

- Symonds MRE, Moussalli A. A brief guide to model selection, multimodel inference and model averaging in behavioural ecology using Akaike's information criterion. Behav Ecol and Sociolobiol. 2011; 65:13-21. https://doi.org/10.1007/s00265010-1037-6

- Summers AP. Stiffening the stingray skeleton an investigation of durophagy in myliobatid stingrays (Chondrichthyes, Batoidea, Myliobatidae). J Morphol. 2000; 243(2):113-26. https://doi.org/10.1002/ (SICI)1097-4687(200002)243:2<113::AIDJMOR1>3.0.CO;2-A

- Summers AP, Koob-Emunds MM, Kajiura SM, Koob TJ. A novel fibrocartilaginous tendón from an elasmobranch fish (Rhinoptera bonasus). Cell Tissue Res. 2003; 312:221-27. https://doi.org/10.1007/s00441003-0714-4

- Tanaka SK. Suction feeding by the nurse shark. Copeia. 1973; 3:606-08. https://doi. org/10.2307/1443135

- Thrush SF, Pridmore RD, Hewitt JE, Cumming VJ. The importance of predators on a sandflat: interplay between seasonal changes in prey densities and predators effects. Mar Ecol Progr Ser. 1994; 107:211222. Available from: https://www.int-res. com/articles/meps/107/m107p211.pdf

- Thrush SF, Dayton PK. What can ecology contribute to ecosystem-based management? Ann Rev Mar Sci. 2010; 2:419-41. https://doi.org/10.1146/annurevmarine-120308-081129

- VanBlaricom GR. Experimental analyses of structural regulation in a marine sand community exposed to oceanic swell. Ecol Monogr. 1982; 52(3):283-305. https://doi. org/10.2307/2937332

- Venables WN, Ripley DB, editors. Morden Applied Statistics with S-Plus. 4th ed. New York: Springer; 2002.

- Wetherbee MB, Cortés E. Food consumption and feeding habits. In Carrier Musick JC, JA, Heithaus MR, editors. Shark and their relatives. Boca Ratón: CRC Press; 2004. p.225-46.

- Witmann JD, Roy K, editors. Marine Macroecology, Chicago: The University of Chicago Press; 2009.

- Zuschin M, Stachowitsch M, Stanton Jr. RJ. Patterns and processes of shell fragmentation in modern and ancient marine environments. Earth Sci Rev. 2003; 63(1-2):33-82. https://doi.org/10.1016/ S0012-8252(03)00014-X 


\section{Neotropical Ichthyology}

OPEN ACCESS

\section{(c) (1)}

This is an open access article under the terms of the Creative Commons Attribution License, which permits

use, distribution and reproduction in any medium,
provided the original work is properly cited.

Distributed under

Creative Commons CC-BY 4.0

๑) 2020 The Authors.

Diversity and Distributions Published by SBI

2 Official Journal of the

Sociedade Brasileira de Ictiologia

SBI

\section{AUTHOR CONTRIBUTIONS}

Jorge M. Roman: Conceptualization, Data curation, Formal Analysis, Investigation, Methodology.

Melisa A. Chierichetti: Conceptualization.

Santiago A. Barbini: Conceptualization, Formal Analysis, Methodology.

Lorena B. Scenna: Conceptualization.

\section{ETHICAL STATEMENTS}

Not applicable.

HOW TO CITE THIS ARTICLE

- Roman JM, Chierichetti MA, Barbini SA, Scenna LB. Feeding habits of the cockfish, Callorhinchus callorynchus (Holocephali: Callorhinchidae) from off northern Argentina. Neotrop Ichthyol. 2020; 18(1):e180126. https://doi.org/10.1590/1982-0224-2018-0126 